\title{
TYPOLOGY OF FOLKLORE FESTIVALS AND PRINCIPLES OF THEIR DIGITAL CONVERSION
}

\author{
Kaloyan Nikolov \\ Institute of Ethnology and Folklore Studies with Ethnographic Museum \\ at the Bulgarian Academy of Sciences, Bulgaria \\ kaloyan.nikolov@iefem.bas.bg
}

\begin{abstract}
An attempt to structure the types of folklore festivals in terms of organizational processes and public significance. Examining the possibilities of creating a digital imprint of events of a folklore nature, which corresponds with the transmission processes of the communities in their quest to preserve the cultural heritage.

Keywords: Folklore Festivals; Live Cultural Heritage; Digital Imprint; Typology of Folklore Festivals
\end{abstract}

\section{ТИПОАОГИЯ НА ФОАКАОРНИТЕ ФЕСТИВААИ И ПРИНЦИПИ НА АИГИТААНАТА ИМ КОНВЕРСИЯ}

\author{
Ка^Оян НиколОв \\ Институт по етнология и ффолклористика с Етнографьски музей \\ при Българска акалемия на науките, България
}

\begin{abstract}
Резюме: Опит за структуриране на виАовете фолклорни фестивали от глеАна точка на организационни процеси и публична значимост. РазглежАане на възможностите за създаване на Аигитален отпечатьк на събитията с фолк^орен характер, кореспондиращ с трансмисионните процеси на общностите в стремежа им за запазване на живото културно наслеАство.

КАючови Ауми: ФОАКАорни фестивали, живо културно наслеАство, цифров отпечатьк, типология на фолклорни фестивали
\end{abstract}

Изследванията в областта на организиране и провеждане на фолклорни феествалите не са много и залачата за типологията на фолклорните феестивали ще има възможни Аопьлнения, неточности и несъответствия. Затова съм вкАючил непретенциозната Аума "опит" в тази работа, с която се застраховам относно бъдещи неуредици.

\section{ВиАове фестивали}

Основните категории по характеристики на фестивалите могат Аa ce структурират в три основни групи (Kutin, 2014) Антропологически, социокултурни и художествени. 
Следвайки категоризирането то Антропологичната група обединява категориите - игра, зрелище, празник. Социокултурнната група се категоризира с пространство, време и институция. Художествената група обелинява - артисти, програма и публика.

Сложността на оценката на различните групи фестивални характеристики, както и задачите и целите на организаторите на съответните събития не Аава коректна възможност за корелация и строгост в определянето на критериите за категоризация. Тук представените характеристики по категории и групи се отнасят изцяло към отворената форма на фестивалите като цяло, което обуславя приемането на характеристиките и на фрестивалите с фолклорна насоченост или наложената терминология - фолк^орен фрестивал. Групираните характеристики по категории и прилагането на критерии за типологизирането на фолклорните фрестивали по общите представени критерии ще бъле многократно улеснена. Представянето на характеристиките и категориите в табличен виА визуализира систематиката, която ще бъле приложена в типологията на фолк^орните фестивали [Фиг. 1].

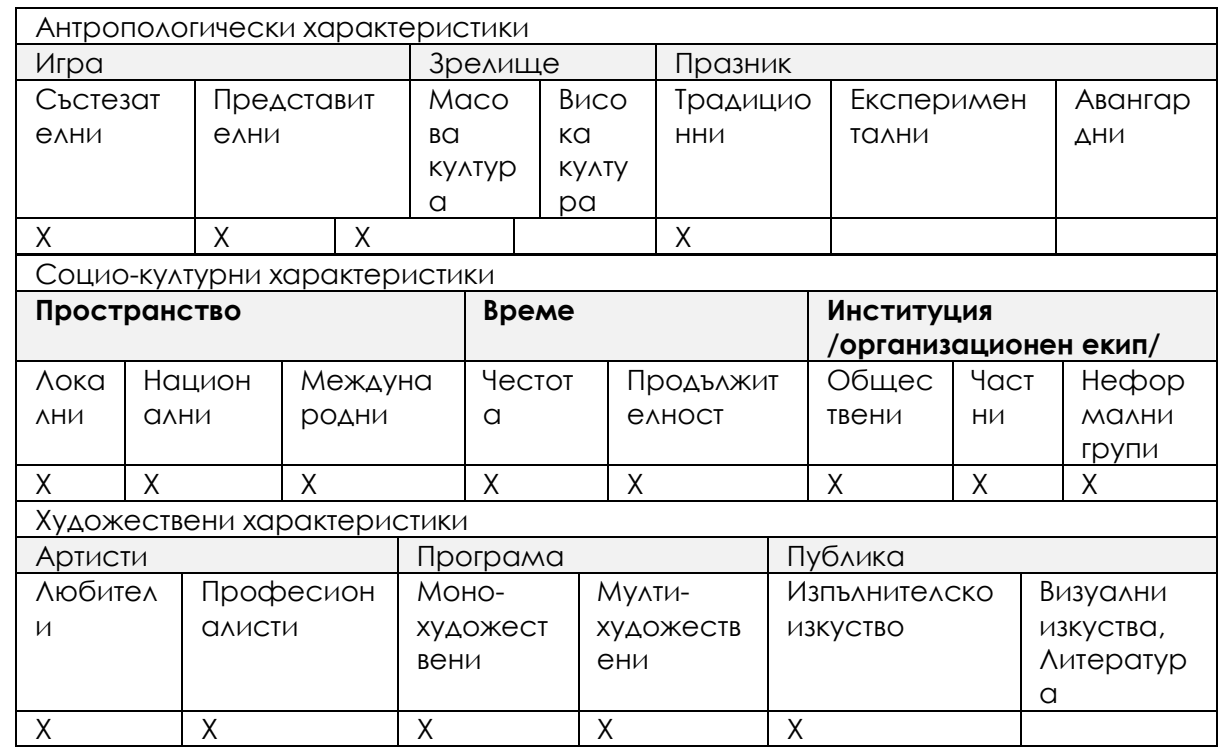

Фиг.1. Типология на фестивалите 
Както се забелязва от схемата фролклорните фрестивали в антропологическите си характеристики се изкґючват от категорията висока култура, експериментални и авангардни феестивали. В социокултурните си характеристики покриват всички категории, а в художествените си характеристики изкАючват Визуални изкуства.

\section{Фолклорни фестивали - типология}

При планиране и организиране на различни обществени мероприятия има минимални изисквания, прави^а и протокол, които

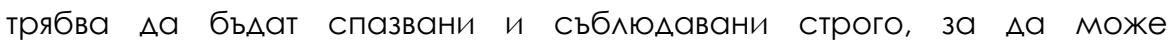
съответното мероприятие $\Delta а$ бъле проведено на нужно ниво и $\Delta а$ откликне на целите и залачите поставени при организирането и провеждането. Всяко обществено мероприятие има своя специорика, която също е необходимо да се вземе в предвиА. Мястото на провежлане, ландшафт, локална култура, комуникационни възможност, метеорология, Аокализация във всеки регион са различни и е наложително $а$ б бълат отчетени при п^анирането и организирането на събитие. Обществените събития биват разнородни по своята цел и причина за провежлане. От традиционни чествания на дьржавни празници, празници от местно значение, спортни мероприятия, мероприятия в сорерата на културата, събори, феестивали, концерти, театрални постановки, храмови празници, изложби Ао партийни срещи, протести, митинги, шествия и Ар. В момента ще се фоокусираме вьрху виАовете фролклорни фрестивали, както и практиките за тяхното организиране и провежАане.

Фолклорните фестивали могат $\Delta а$ бъдат разделени на няколко виАа по слеАните критерии:

- Антропологически характеристики

- Презентационни

- Сьстезателен характер

- Социо-културни характеристики

- Териториален обхват

- Времеви обхват 

- Организационен орормат
- Цел на провежлане
- Художествени характеристики
- Профресионалисти
- ^юбители

Ще направим типологична систематика на видовете провежлани фрестивали с фролклорна насоченост. Вьв врьзка с антропологическите характеристики, свързани с провежАането на фоллклорни фрестивали можем $А$ о опреАелим Ава основни виАа:

\section{а. Фолклорен фестивал без състезателен характер} /Прелставителни или презентационни/ - Този виА фрестивали се организират и провежлат с определена насоченост и наблягане на съпьтстващи цели и събития. Прелставяне на участниците пред широка публика в комбинация сьс сьпьтстващи мероприятия (Panayotov, 2010).

b. Фолклорен фестивал със състезателен характер - Тези фрестивали могат $а$ с се разделят на две основни групи: (1) Слабо засегнат сьстезателен елемент - В тези фестивали обикновено са с неясна структура на състезателния характер и участващите групи получават Аипломи за участие придружени сьс степени за качество на изпьлнениея (2) Силно засегнат състезателен елемент: (1) Споралично организирани феестивали сьс строга и ясно поставени залачи и критерии за оценка на изпьлненията, построена йерархична структура на оценяването с награнна система; (2) Мрежова йерархична структура от орестивали с уеднаквени критерии на състезателния характер (EAFF, n. d.).

\section{СОЦИО-КУАТУРНИ ХАРАКТЕРИСТИКИ}

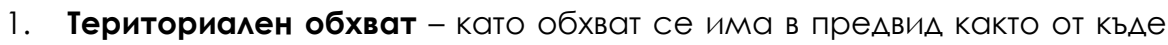
са участващите групи, както и значението на фрестивала.

- Местни - ^окални фролк^орни фрестивали - събори (Marinov, 2003)

- Регионални фолклорни фестивали

- Национални фолклорни феестивали

- МежАународни фролклорни фрестивали - WAFF (WAFF, 2020) 


\section{2. Времеви обхват}

\section{3. ЦикАичност на провежАане}

\section{4. ПроАължителност на провежАане}

5. Организационен формат - може $\Delta$ а се разгледа начина на оринансиране в комбинация с преАхоАно представените критерии.

- Пьлно фринансиране от спонсори на организационния комитет. В този случай се фринансират, както транспортните разхоли $А$ о мястото на организиране на фестивала, така и настаняването и изхранването на участниците и всички организационни разхоли на организационния комитет.

- Финансиране от местената власт

- Финансиране от спонсори и рекламни кампании

- Финансиране от Аьржавни институции

- Съвместно фринансиране от спонсори и институции.

- Частично фринансиране - в този случай от пьлното финансиране се изкюючват транспортните разходи на участниците Ао мястото на провежАане на фрестивала.

- Самофинансиране - в този случай всичките разходи за организирането на орестивала, транспортните разхоли, настаняването и изхранването на участниците се поема от самите участници поА фоормата на такси за участие или вХоАни билети. Организационния комитет изчислява общите разходи нужни за фоннансиране на фрестивала. В тези разхоли се калкулират разхоли на организационния екип, сцени, озвучаване, поларьци и др. Намират си подходящи места за настаняване на участниците. /Местата за настаняване трябва $А а$ са приятни за преживяване, изхранването трябва $\mathrm{a}$ с се съобрази с възможностите на местата за настаняване и

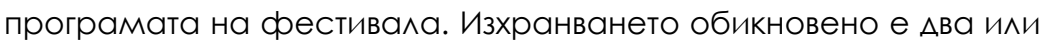
три пьти Аневно. Въз основа на възможностите за настаняване, броя на концертите и прольлжителността на концертите се определя капацитет на орестивала. Това количеството участници, които може Аа участват на феестивала. Въз основа на количеството на участниците може $\Delta а$ се изчисли и таксата за 
участие, която се обявява. В таксата за участие /когато е калкулирана като пакет услуги, участие, настаняване, транспорт/ е добре $л а$ се предвиди 10\% от цената за комисионна за туристически агенции или организации подпомагащи различните групи за участие в съответния фрестива^.

- Самофинансиране с частично финансиране от спонсори или местна власт. В зависимост от Аоговореното фринансиране на фестивала, то обявената такса за участие може $\Delta а$ бъле намалена. По този начин се полпомага по-масово участие във фестивала.

6. Цел на провежлане - основната цел на всички провежлани фолккорни фестивали е обмена и сполелянето на фолклорното Изкуство, СъзАаване на нови контакти и връзки, популяризиране на фолклорното изкуство, запазване на интереса на групите пресъзааващи и представящи тралиционните фрорми на изкуство и култура, както и активирането на носителите на културното наследство да го споделят и предават на следващите поколения. СпореА съпьтстващите цели на провежлане можем да проследим определени насочености ICH Convention (ICH Convention 2003, 2020).

7. Туристическа насоченост - сполеляне и популяризиране на туристическите и историческите далености на територията на провежлания орестивал. Представяне на специфичен продукт или услуга характерно за съответното населено място или регион. (Stoilova, 2017)

8. Полпомагане на икономическото състояние на региона.

\section{ХУАОЖЕСТВЕНИ ХАРАКТЕРИСТИКИ}

Продресионалисти - орормата на организиране и провежАане на феестивали с участието на профресионални изпьлнители е характерно използването на стандартните организационни метоли за фонансиране от продажба на билети за съответното събитие. 
Аюбители - фрормата на провежАане на фолклорни фрестивали с участници на ^юбителски сьстави и изпьлнители е характерна сьс своболен вхоА на зрителската аудитория.

\section{ПРАВНА РАМКА И ИЗИСКВАНИЯ}

За организирането на обществено мероприятие е необходимо Аа има учрелено юрилическо мице, което да поеме организационната отговорност, заплащане на разхоли по организация и провежлане. Обикновено за организирането на фолклорни фестивали се използват структурите на читалища, културни отАели на кметства ^и общини, юрилически лица с нестопанска цел, юридически лица със стопанска цел, туристически агенции.

В зависимост от законовата уредба е необходимо $а$ с се спазват както законите за обществен рел, зАравеопазване, така и законите на счетоводство.

Ако организационния комитет на фрестивала е приел политика на пьлно обслужване на участниците, в което са вк^ючени както организирането на изявата, така и организирането на настаняването и изхранването на участниците, то е зальлжително организационната компания или Аа притежава туристически ^иценз или Аа има сключен Аоговор за сътрудничество с туристическа компания - туристически оператор ими туристически агент.

\section{МЕАИЙНО ОТРАЗЯВАНЕ И ПОПУАЯРИЗИРАНЕ}

Използването на масовите комуникационни среАства, като телевизии, ралиа, вестници, социални мрежи, Интернет платорорми, Интернет пространство са изключително важни за стадиите при организирането и провежАането на фолклорните фрестивали.

- Набиране на участници

- Популяризиране на събитието за набиране на публики за концертните изяви

- Изльчване на живо по телевизии, Интернет платорорми и социални мрежи

- Отразяване на събитието

- Сьпьтстващи мероприятия и събития 
- Фолклорните фестивали имат голям потенциал за провежлане на съпьтстващи мероприятия и събития изразяващи се в:

○ Изложби

- Етнографоски изложби

- Кулинарни изложби

- Фотографрски изложби

- Кулинарни събития

- Занаятчийски изложения

- Търговски изложения

- Майсторски класове, обучителни курсове

- Конореренции, семинари

- Има и случаи, когато фолклорен фрестивал се явява сьпьтстващо събитие на Аруги организирани мероприятия, като конференции, браншови представяния, панаири и мр.

\section{АИГИТААЕН ОТПЕЧАТЪК}

С навлизането в новото хилялолетие, развитието на инорормационните технологии преАлагат все по-удобни начини за популяризиране и архивиране с цел бълещо използване на резултатите от провелените фолклорни фестивали. Запечатването на моментното състояние на живото културно наследство е важен елемент за неговото съхранение и трансмисия.

Почти пьлното блокиране на икономическия И културен живот на планетата заради пандемичната обстановка при COVID 19 наложи бърза промяна на нагласата на човечеството за използването на модерните комуникационни средства. В условията на социална Аистанция се наложи $\Delta$ a се търсят алтернативни начини за провежлането на фолклорните фрестивали. От пренесените изцяло във виртуална срела фролклорни фестивали преоблалават фестивалите със състезателен характер. Изгралените електронни платорорми за гласуване от публика и журираща комисия набират все по-голяма популярност. ПреАимствата на иновативния поАХоА са, че чувствително се съкращават оринансовите разхоли, многократно се увеличава Аостьпа на публика Ао концертните изяви и в резултат на провежлането 
остава качествено структуриран Аигитален отпечатьк. Като основен недостатьк може $\mathrm{a}$ се изтькне неосьществения социален контакт межАу публика и участници, както и межАу различните участващи групи (EAFF, n. d.).

\section{AИTEPATYPA / REFERENCES}

EAFF (n. d.). European Association of Folklore Festivals - EAFF, [www.eaff.eu, (Last view: 15.01.2020)].

ICH Convention 2003, U. (2020). Dive into intangible cultural heritage!, UNESCO CONVENTION $2003 \quad \mathrm{ICH}$, [https://ich.unesco.org/en/dive\&display=domain\#tabs, (Last view: 14.01.2020)].

Kutin, L. (2014). Bulgarian festivls - categires, system of examination. Sofia: Avangard prima.

Marinov, D. (2003). Praznicite s obredite i obichaite (in Bulgarian). From D. Marinov, Religia i narodni obichai. Publisher: "Izłok-zapad", Sofia, Bulgaria, p. 24 // [Маринов, А. (2003). Празниците с обредите и обичаите. От А. Маринов, Религия и народни обичаи (стр. 24). Сор.: Иза."Изток-ЗапаА"].

Panayotov, K. (2010). Sacrifice (Kurban) - Types of Documents, Clasifications and Collections. Bulgarian Folklore(3-4), 92-99.

Stoilova, E. (2017). Festivity and Construction of Local Cultural Heritage. Safeguarding of Cultural Heritage - Ideas and practices, 212-222.

WAFF (2020). WAFF org. [www.waff.org, (Last view: 15.01.2020)]. 


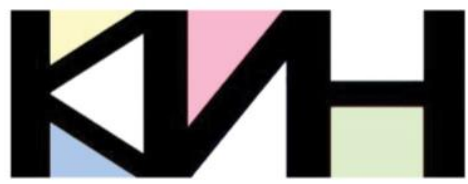

КУАТУРНО-ИСТОРИЧЕСКО НАСАЕАСТВО:

ОПАЗВАНЕ, ПРЕАСТАВЯНЕ, АИГИТААИЗАЦИЯ

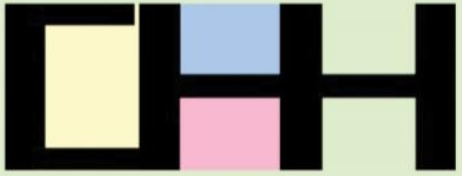

CULTURAL AND HISTORICAL HERITAGE: PRESERVATION, PRESENTATION, DIGITIZATION
Материалите в сборника са обект на авторско право. Разрешава се безвъзмезАното ползване на техни електронни/ хартиени копия само за лична употреба или обучение, при пь^но цитиране на текущата страница и слеА писмена декларация от цитиращия за мипса на търговски намерения.

(с) Авторски колектив, 2020

Техническо реАактори: Калина Сотирова-Вълкова Николай Ноев Паска^ Пиперков

\section{Editors}

Petko St. Petkov

Galina Bogdanova

This work is subject to copyright. Open and free of charge use of digital/hard copies of publications is granted only for personal or educational use, with full citation of the current page, and after written declaration of the quoting side for notcommercial Intention.

(C) Authors` Group, 2020

Technical editors:

Kalina Sotirova-Valkova

Nikolay Noev

Paskal Piperkov

НАЦИА регистрационен № 1209

Научна пореАица: том 6, брой 2 (9)/2020

Science series: vol. 6 , issue $2(9) / 2020$

NCID Registry No. 1209

www.math.bas.bg/vt/kin

ISSN: 2367-8038 